\title{
Nutrient Cycling in Grazed Pastures ${ }^{1}$
}

\author{
Maria L. Silveira, Joao M. B. Vendramini, Hiran M. da Silva, and Mariana Azenha²
}

\section{Introduction}

Many forage-based livestock production systems in Florida are characterized by extensive grazing with minimal inputs of commercial fertilizer and supplemental feed. In these systems, adequate soil fertility conditions are essential to sustain forage production. If nutrients become deficient, pasture and animal performance is reduced, and the economic returns of livestock operations may decline.

Nutrients in grazed pastures are cycling among several pools, including the atmosphere, soil, plant, and grazing animals (Figure 1). Several factors, such as climatic conditions, soil type, plant species, and grazing management, can affect nutrient dynamics in these pools. Management alternatives, such as stocking method, grazing intensity, strategic fertilization, and the use of legumes, can promote nutrient cycling and enhance soil fertility conditions, which can improve forage productivity and sustainability.

Nutrients may enter forage systems as fertilizer, animal feed, as well as through atmospheric deposition. In contrast, nutrients are exported from the system as animal product, harvested forage, leaching, and runoff. When nutrient removal rates exceed inputs, one or more nutrients become deficient in the soil, leading to reduced pasture and animal performance. This EDIS publication discusses the different nutrient pathways in grazing pastures to help producers better understand how to promote nutrient cycling and pasture sustainability.

\section{Pathways of Nutrient Cycling in Grazing Pastures}

Grazing cattle retain only a small portion of ingested nutrients compared to the amount excreted in feces and urine. Approximately $70 \%-90 \%$ of the nitrogen $(\mathrm{N})$, phosphorus $(\mathrm{P})$, and potassium $(\mathrm{K})$ ingested as feed (forage and/or supplement) are recovered in excreta and urine (Haynes and Williams 1993; Williams and Haynes 1990). Therefore, nutrients can be recycled back to the pasture through animal excreta and represent an important source of $\mathrm{N}$, $\mathrm{P}$, and $\mathrm{K}$ for forage crops. In low-input systems, nutrients recycled through animal excreta may be responsible for up to $70 \%$ of annual pasture production (Haynes and Williams 1993; Dubeux et al. 2007; Dubeux et al. 2009). Research has shown that nutrient cycling in grazed pastures can result in greater forage productivity and persistence, compared to hay production or unharvested forage (Franzluebbers, Wilkinson, and Stuedemann 2004). However, distribution of excreta in the grazing pastures is often not uniform. A significant proportion of the nutrients may be concentrated in relatively small areas, generally near shade and water resources where cattle congregate (Mathews et al. 1994; Mathews, Sollenberger, and Tritschler 1996; Dubeux et al. 2007).

Grazing management is important for improving nutrient distribution and availability in grazed pastures (Briske and Heitschmidt 1991; Lavado, Sierra, and Hashimoto 1996). Rotational stocking with short grazing intervals

1. This document is SL376, one of a series of the Department of Soil and Water Sciences, Florida Cooperative Extension Service, Institute of Food and Agricultural Sciences, University of Florida. Original publication date January 2013. Please visit the EDIS website at http://edis.ifas.ufl.edu.

2. Maria L. Silveira, associate professor, Department of Soil and Water Science, Range Cattle Research and Education Center, Ona, FL; Joao M.B. Vendramini, associate professor, Agronomy Department, Range Cattle Research and Education Center, Ona, FL; Hiran M. da Silva, PhD candidate, Federal Rural University of Pernambuco, Brazil; Mariana Azenha, PhD candidate, Sao Paulo State University, Brazil; Florida Cooperative Extension Service, Institute of Food and Agricultural Sciences, University of Florida, Gainesville, FL 32611. 
Livestock

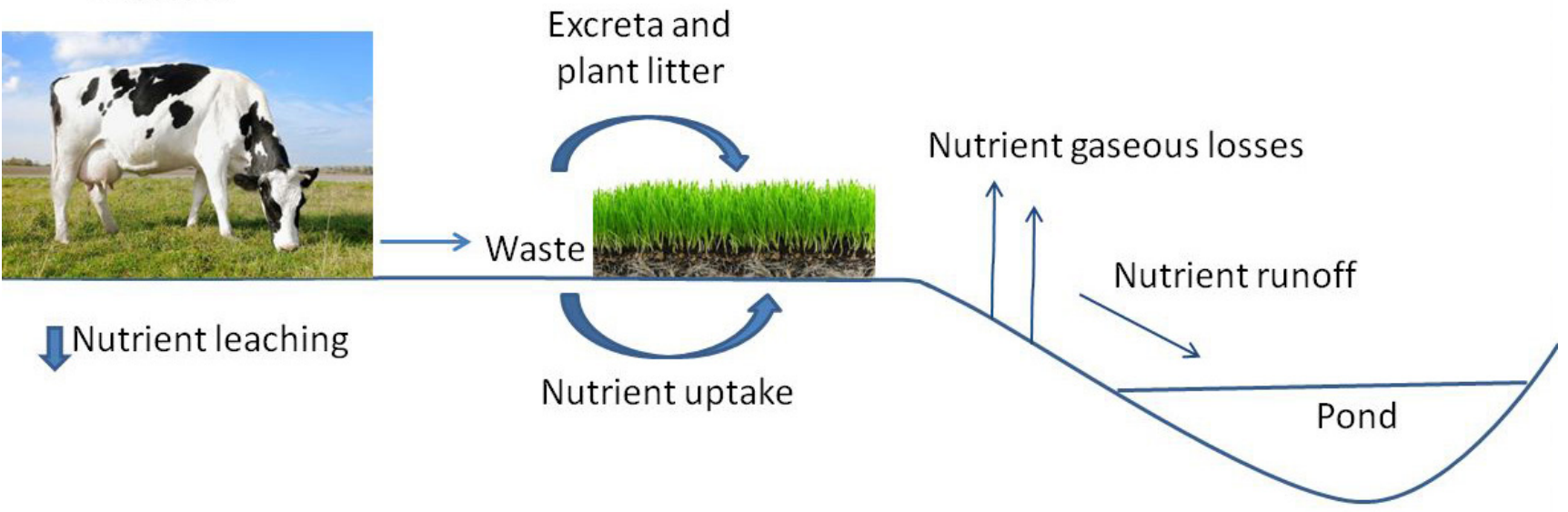

Figure 1. Schematic diagram showing how nutrients cycle through several pools, including the atmosphere, soil, plants, and animals. Credits: Maria L. Silveira and http://www.thinkstock.com

often results in more uniform nutrient distribution than continuously stocked pastures (Haynes and Williams 1993). Research has also shown that intensifying pasture use by increasing stocking rates significantly affects excreta distribution, nutrient cycling, and redistribution in soils (Forbes and Rouquette 2007). Nutrient recycling is often accelerated at high stocking rates because forage utilization is high and results in less plant litter. Plant litter plays a minor role in nutrient cycling because mineralization rates of excreta are faster than for plant litter (Thomas 1992). Thus, using grazing management that promotes more uniform distribution of nutrients can potentially reduce fertilizer requirements and the risks associated with nutrient buildup in the soil, especially when stocking rates are high (Mathews, Sollenberger, and Tritschler 1996; Peterson and Gerrish 1996).

Nutrient distribution in a pasture may also change with livestock tolerance to solar radiation, particularly in warm climates. Cattle breed and coat color may interact with environmental conditions, and can affect pasture utilization and nutrient redistribution patterns. In this regard, Brahman cattle spent less time under shade than non-Brahman cattle, and Holstein cows with predominantly black coats spent $20 \mathrm{~min} /$ day more time under shade in Florida compared to predominantly white-coated cows (Macoon 1999). Because there is a correlation between time spent in a particular pasture area and the number of excretions (White et al. 2001), the more time the cattle spends under the shade, the greater the nutrient concentration in that area (i.e., less uniformity of distribution). Therefore, less excreta is deposited in the remaining pasture. This finding also correlates with increasing air temperature or the temperature-humidity index.
Another important pathway for nutrients to be recycled in grazed pastures is through plant material. It is important to emphasize that grazing animals and plant litter are not a source of nutrients to the pasture. Grazing animals and plant litter are actually pathways for nutrients to be recycled within the pasture system. Senescent plant material and litter are returned to the soil, and over time they become part of the soil organic matter. The relative contribution of plant litter versus animal excreta in terms of nutrient cycling will depend on the stocking rate. Under high stocking rates, more nutrients are recycled through animal manure, while at low stocking rates, nutrient turnover through plant litter may be favored (Sollenberger et al. 2002).

Nutrient returns from senescent litter are more uniformly distributed than returns from animal excreta, but only minimal amounts of nutrients are expected to derive from litter recycling in intensively managed pastures (Wedin 1996). Because of the chemical characteristics of tropical grasses (including higher lignin content), litter of tropical grass pastures decomposes more slowly than temperate grasses. A major factor that affects litter decomposition is the carbon to nitrogen $(\mathrm{C}: \mathrm{N})$ ratio of the plant or animal material. Because warm-season grasses normally exhibit low tissue nitrogen concentrations, their C:N ratios tend to be greater than those of cool-season (temperate) species. Under high C:N ratios ( $>30)$, the microorganisms decomposing the litter "compete" with pasture plants for nutrients. This process is known as nutrient immobilization, and it is often associated with $\mathrm{N}$ deficiency and subsequent decrease in forage production, nutritive value, and, ultimately, pasture persistence. Pasture management strategies that improve litter quality, such as $\mathrm{N}$ fertilization or the use of legumes, can promote litter decomposition and increase nutrient availability to the forage. 


\section{Conclusion}

Nutrient cycling is particularly important in warm-climate pasture systems that are managed extensively and receive little or no fertilization. Animal manure (excreta) and plant litter represent the most important pathways for nutrients to be recycled in grazed pastures. From a practical standpoint, factors that contribute to a more uniform distribution of excreta and strategies that improve plant litter quality can promote nutrient cycling and pasture sustainability.

\section{References}

Briske, D.D., and R.K. Heitschmidt. 1991. "An Ecological Perspective." In Grazing Management: An Ecological Perspective, edited by R.K. Heitschmidt and J.W. Stuth, 11-26. Portland, OR: Timber Press.

Dubeux, J.C.B., Jr., L.E. Sollenberger, B.W. Mathews, J.M. Schoberg, and H.Q. Santos. 2007. "Nutrient Cycling in Warm-Climate Grasslands.” Crop Sci. 47:915-28.

Dubeux, J.C.B., Jr., L.E. Sollenberger, L.A. Gaston, J.M.B. Vendramini, S.M. Interrante, and R.L. Stewart. 2009. "Animal Behavior and Soil Nutrient Redistribution in Continuously Stocked Pensacola Bahiagrass Pastures Managed at Different Intensities." Crop Sci. 49:1503-10.

Forbes, T.D.A., and F.M. Rouquette, Jr. 2007. "ForageAnimal Interface: Grazing Behavior and Nutrient Intake." In Encyclopedia of Animal Science. New York, NY: Taylor \& Francis Group.

Franzluebbers, A.J., S.R. Wilkinson, and J.A. Stuedemann. 2004. "Bermudagrass Management in the Southern Piedmont USA: X Coastal Productivity and Persistence in Response to Fertilization and Defoliation Regimes." Agron. J. 96:1400-11.

Haynes, R.J., and P.H. Williams. 1993. "Nutrient Cycling and Soil Fertility in the Grazed Pasture Ecosystem." Adv. Agron. 49:119-99.

Lavado, R.S., J.O. Sierra, and P.N. Hashimoto. 1996. "Impact of Grazing on Soil Nutrients in a Pampean Grassland.” J. Range Manage. 49:452-7.

Macoon, B. 1999. "Forage and Animal Responses in Pasture-Based Dairy Production Systems for Lactating Cows." PhD. Diss. Gainesville: University of Florida.
Mathews, B.W., L.E. Sollenberger, and J.P. Tritschler II. 1996. "Grazing Systems and Spatial Distribution of Nutrients in Pastures: Soil Considerations." In Nutrient Cycling in Forage Systems, edited by R.E. Joost and C.A. Roberts, 213-29. Proc Potash and Phosphate Inst and the Foundation for Agron Res, Columbia, MO, March 7-9 1996. PPI, Norcross, GA.

Mathews, B.W., L.E. Sollenberger, V.D. Nair, and C.R. Staples. 1994. "Impact of Grazing Management on Soil Nitrogen, Phosphorus, Potassium, and Sulfur Distribution." J. Environ. Qual. 23:1006-13.

Peterson, P.R., and J.R. Gerrish. 1996. "Grazing Systems and Spatial Distribution of Nutrients in Pasture: Livestock Management Considerations." In Nutrient Cycling in Forage Systems, edited by R.E. Joost and C.A. Roberts, 203-12. Proc Potash and Phosphate Inst and the Foundation for Agron Res, Columbia, MO, March 7-9, 1996, PPI, Norcross, GA.

Sollenberger, L.E., J.C.B. Dubeux, Jr, H.Q. Santos, and B.W. Mathews. 2002. "Nutrient Cycling in Tropical Pasture Ecosystems." In Reuniao Annual da Soc Bras Zootecnia SBZ, edited by Batista et al., 151-79. Recife, PE.

Thomas, R.J. 1992. "The Role of the Legume in the Nitrogen Cycle of Productive and Sustainable Pastures." Grass Forage Sci. 47:133-42.

Wedin, D.A. 1996. "Nutrient Cycling in Grassland: An Ecologist's Perspective." In Nutrient Cycling in Forage Systems, edited by R.E. Joost and C.A. Roberts, 29-44. Proc Potash and Phosphate Inst and the Foundation for Agron Res, Columbia, MO, March 7-9, 1996. PPI, Norcross, GA.

White, S.R., R.E. Sheffield, S.P. Washburn, L.D. King, and J.T. Green, Jr. 2001. "Spatial and Time Distribution of Dairy Cattle Excreta in an Intensive Pasture System." J. Environ. Qual. 30:2180-7.

Williams, P.H., and R.J. Haynes. 1990. "Influence of Improved Pastures and Grazing Animals on Nutrient Cycling within New Zealand Soils." New Zealand J. Ecol. 14:49-55. 